\title{
REDISCOVERY OF FIMOSCOLEX SPORADOCHAETUS MICHAELSEN 1918 (CLITELLATA: GLOSSOSCOLECIDAE), AND CONSIDERATIONS ON THE ENDEMISM AND DIVERSITY OF BRAZILIAN EARTHWORMS
}

\author{
Samuel W. JAMES ${ }^{1}$ \& George G. Brown ${ }^{2}$ \\ ${ }^{1}$ University of Kansas Biodiversity Institute, Dyche Hall, Lawrence, KS, 66045, USA, e-mail: \\ sjames@ku.edu \\ ${ }^{2}$ Embrapa Florestas, Estrada da Ribeira, km. 111, C.P. 319, Colombo, PR, 83411-000, Brazil, e-mail: \\ browng@cnpf.embrapa.br
}

James, S. W. \& G. G. Brown. 2010. Rediscovery of Fimoscolex Sporadochaetus Michaelsen 1918 (clitellata: glossoscolecidae), and considerations on the endemism and diversity of Brazilian earthworms. Acta Zoológica Mexicana (n.s.), Número Especial 2: 47-58.

ABSTRACT. Brazil hosts approximately 305 earthworm species, of which $260(85 \%)$ are native and 46 (15\%) exotic. Most of the native species (80\%) are known from only one or a few sites, and two species were considered as extinct by the Ministry of Environment of Brazil in 2003, due to lack of sightings, habitat destruction and a limited prior known distribution (endemism). One of these, Fimoscolex sporadochaetus Michaelsen, 1918 was recently found in a forest reserve (Parque Estadual do Itacolomi), near the reservoir Bacio do Custódio in Ouro Preto, Minas Gerais. With this finding, and based on earthworm collection data in Brazil up to now, we believe that the endangered and "extinct" species should have their status reviewed, and that further collecting efforts are urgently necessary to adequately determine the extent of earthworm biodiversity in Brazil and the present level of threat to their survival.

Key words: Endangered species, Oligochaeta, biodiversity, native species.

James, S. W. \& G. G. Brown. 2010. Redescubrimiento de Fimoscolex Sporadochaetus Michaelsen 1918 (clitellata: glossoscolecidae), y consideraciones sobre el endemismo y la diversidad de lombrices de tierra brasileñas. Acta Zoológica Mexicana (n.s.), Número Especial 2: 47-58.

RESUMEN. En Brasil hay aproximadamente 305 especies de lombrices de tierra, de las cuales 260 (85\%) son nativas e 46 (15\%) exóticas. La mayor parte de las especies nativas (80\%) es conocida de apenas una o dos localidades y dos especies fueron consideradas como extintas por el Ministerio del Medio Ambiente de Brasil en 2003, debido a la falta de registros, destrucción de hábitat y distribución limitada (endemismo). Una de ellas es Fimoscolex sporadochaetus Michaelsen 1918, que fue recién encontrada en una reserva de Bosque Atlántico (Parque Estatal de Itacolomi) próximo al Embalse del Custodio, en el municipio de Ouro Preto, Minas Gerais. Basándonos en los datos de colectas de lombrices de tierra realizadas en Brasil hasta el momento, creemos que el estado de las especies amenazadas y "extintas" debe ser revisado y que mayores esfuerzos de colecta son necesarios para determinar la biodiversidad de lombrices en el país y su estado actual de amenaza.

Palabras clave: especies amenazadas, Oligochaeta, biodiversidad, especies nativas.

Recibido: 16/05/2008; aceptado: 08/01/2010. 


\section{INTRODUCTION}

The annelids were among the first animals to appear on the face of the earth, probably originating in the Ediacarian, over 600 million years ago (Bouché 1983). From the ocean, they colonized the earth's landmass and adapted to life in the soil around 225 million years ago. Therefore, considering the time they have had to evolve and adapt to life in soil (a dark, compact medium with low quality and quantity of food), it is not surprising that the present diversity of oligochaetes in the world surpasses 8000 species (Reynolds \& Wetzel 2010), of which approximately 50\% are earthworms (megadriles). It is possible that as many as 8000 species of megadrili may inhabit the earth, although at present only around 3800 have been described (Reynolds 1994).

The biodiversity and ecology of earthworms in Brazil was recently reviewed by James \& Brown (2006) and Brown \& James (2007). The authors reported 305 species in 64 genera, of which 253 species were native to the country. Of these, more than 40 species were new to science and must still be described. Since these papers were written, several additional new species have been found, and many more will likely be encountered as sampling efforts increase, particularly in some parts of the country (i.e., Northeastern Brazil).

In March 2003, the Ministry of Environment of Brazil published the official list of endangered species in Brazil (MMA 2003). The information was the result of the 2002 meeting on endangered species in Belo Horizonte, Minas Gerais (MG). A complete list of Brazilian endangered plants and animals was later published as a book edited by Machado et al. (2005). As usual, the status of the "endangered" species was evaluated based on expert scientific opinion and data. Nevertheless, no earthworm expert participated in the 2002 meeting, as the earthworm taxonomist Gilberto Righi was already deceased.

In previous meetings on endangered species, Righi had participated, providing data for the evaluation of the status of possibly endangered earthworms. According to Righi (1998), three earthworm species from Minas Gerais could be considered endangered: Fimoscolex sporadochaetus Michaelsen 1918, Rhinodrilus alatus Righi 1971 and Rhinodrilus fafner Michaelsen 1918. All species were considered endangered due mainly to habitat alteration and possible restricted home ranges. In addition, $R$. alatus was considered endangered due to over-exploitation by collectors to be sold as fish bait, mainly in the region surrounding Paraopeba, MG. Nevertheless, despite the absence of an earthworm expert at the 2002 meeting, F. sporadochaetus and $R$. fafner were declared extinct.

In the present paper, we report the rediscovery of $F$. sporadochaetus, based on material collected in an expedition to Belo Horizonte and Ouro Preto region, MG. Furthermore, this paper provides some additional considerations on "endangered" species and their diversity in Brazil, based on the author's recent collection efforts and a review of the literature. 


\section{REDISCOVERY OF FIMOSCOLEX SPORADOCHAETUS MICHAELSEN, 1918}

While collecting earthworm specimens for purposes other than new species discovery or accumulating new records of previously known species, the authors visited several sites in Minas Gerais (MG) state in February of 2006. In order to obtain members of the Fimoscolex, an attempt was made to re-locate the previous record of $F$. sporadochaetus published in Righi (1971a). The collection data in the Museu de Zoologia at the University of São Paulo stated that Righi's specimens were collected in secondary forest near the base of a wall surrounding a motel near Conselheiro Lafaiete, MG, at km 418 on the road from Rio de Janeiro to Belo Horizonte. Unfortunately, the numbering system on the road did not agree with Righi's data. Local inquiries failed to uncover a connection to a previous numbering system, but one informant said a motel had been demolished some time back. However, we were unable to find enough information to guide us to a likely location. The next scheduled stop was Lavras Novas, MG. Near that town in the forest of the Parque Estadual do Itacolomi, adjacent to the reservoir Bacio do Custodio (Fig. 1) we collected numerous earthworm species, among them $F$. sporadochaetus. The following description is based on the specimens collected and the data presented in Michaelsen (1918) and Righi (1971a).

Fimoscolex Michaelsen, 1900

Setae eight per segment, in regular longitudinal lines, at least in anterior and/or middle regions of the body, single midventral intra-clitellar male pore. Calciferous glands of composite tubular structure, one pair in segment 11 and/or 12. Metandric, metagynous; seminal vesicles long, passing through several septa, copulatory chamber single, spermathecae absent.

Fimoscolex sporadochaetus (see Fig. 2)

Michaelsen, 1918 Zool. Jb. Syst. 41, p. 299

Righi, 1971 Pap. Avulsos Zool. 25, p. 10

Material examined. Five adults, three juveniles from forest ravine soil near Bacio do Custódio, Lavras Novas, MG, Brasil. 20² 27.748' S, 43² 29.516’ W, 1190 masl, 7 February 2006. G. Brown, S. Davidson, N. Pinel, S. James colls.

External characters: Unpigmented, prostomium prolobous, body dimensions 40$60 \mathrm{~mm}$ long, 2.5-3.5 mm diameter, greatest at clitellum; 190-205 segments. Clitellum $\mathrm{xv}$-xxiii, annular; large conical male porophore with single slit-like male pore midventral in xvii, occupying most of ventral surface of segments xvi-xviii, female pores not seen; no other genital pores. Nephropores a single rank at setal line b. Setae 8 per segment starting in segment vi, in regular lines in preclitellar segments, and there very closely paired ( $\mathrm{ab}, \mathrm{cd}<0.1 \mathrm{~mm}$ ); setal pairing becomes wider towards segment $\mathrm{xx}$, and thereafter irregular $\mathrm{ab}, \mathrm{cd}$ from $0.4-0.7 \mathrm{~mm}$; $\mathrm{b}$ setae generally just ventral to nephropores. Setae of posterior-most 20-25 segments much larger, and more widely spaced within segments. 


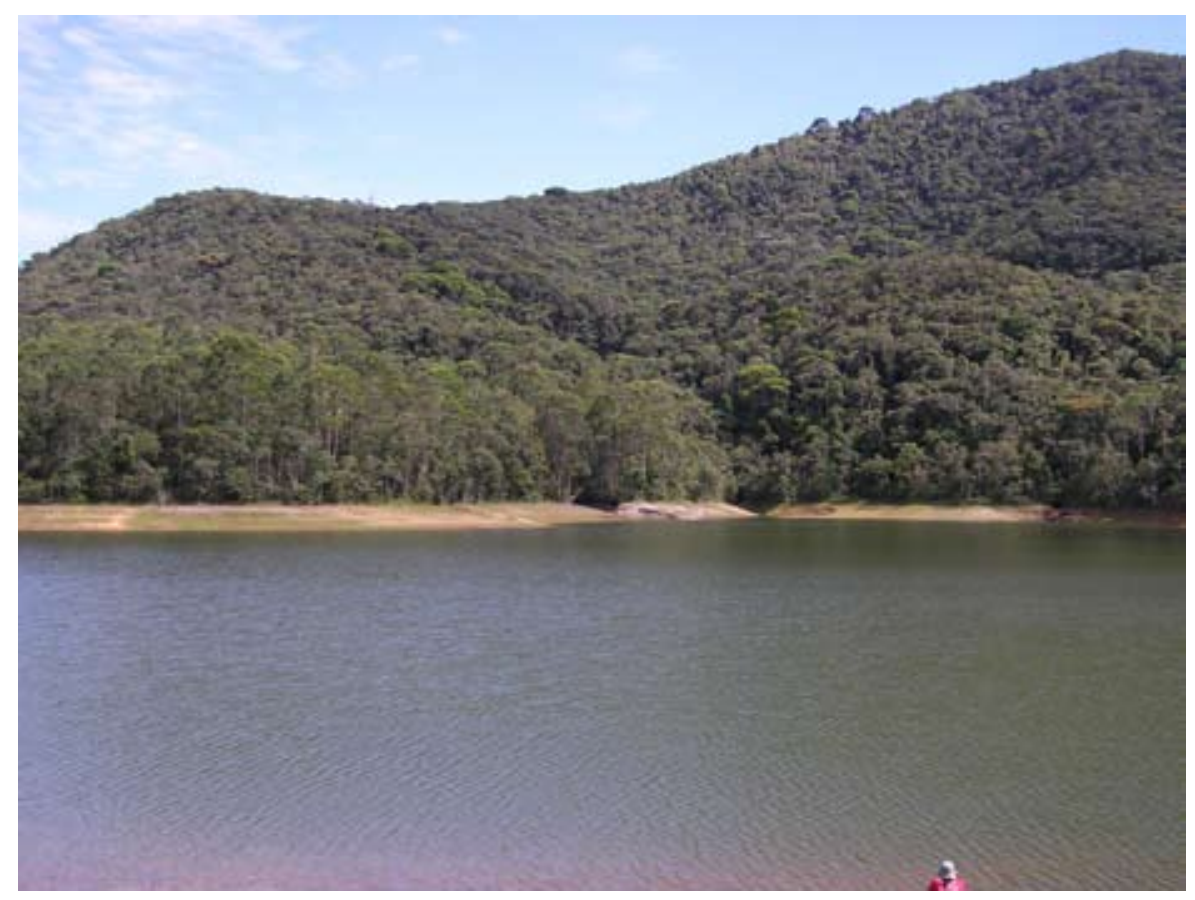

Figure 1. View of the forest (background) at the Itacolomi State Park (Ouro Preto county, Minas Gerais) in which F. sporadochaetus was found, with the Bacia do Custodio in the foreground. (Photo S.K. Davidson)

Internal characters: Anterior septa 6/7-10/11 muscular, following septa very thin until septa 13/14, 13/14-22/23 with thickened white dorsal sections, septa 13/1418/19 fused dorsally. Gizzard in vi, calciferous glands paired in xii, of intertwined tubular structure. Typhlosole lamellar in sinuous zig-zag folds of large amplitude from xvii-xxi, smaller amplitude but depth of lamella approximately constant, never folded over in pockets fused to a central linear part of typhlosole. Hearts vii-ix lateral, $\mathrm{x}$-xi esophageal, hearts of xi inside testes sacs of segment xi. Seminal vesicles from large sac at 11/12 as narrow tubes passing through septa posteriorly, reaching as far as segment lxx; slightly pinnate structure with very small lobes symmetrically branching from a central canal. Copulatory chamber not coelomic, but embedded within the body wall enlarged as the conical porophore; vasa deferentia from the testicular funnels in the testes sacs of segment xi, septum 11/12 directly to body wall and superficial until diving into body wall near $16 / 17$.

Remarks: The specimens examined agreed in all respects with the description in Michaelsen (1918), based on material from Gorduras, MG. Righi's material was slightly divergent but not in any important ways. In our experience, $F$. sporadochae- 


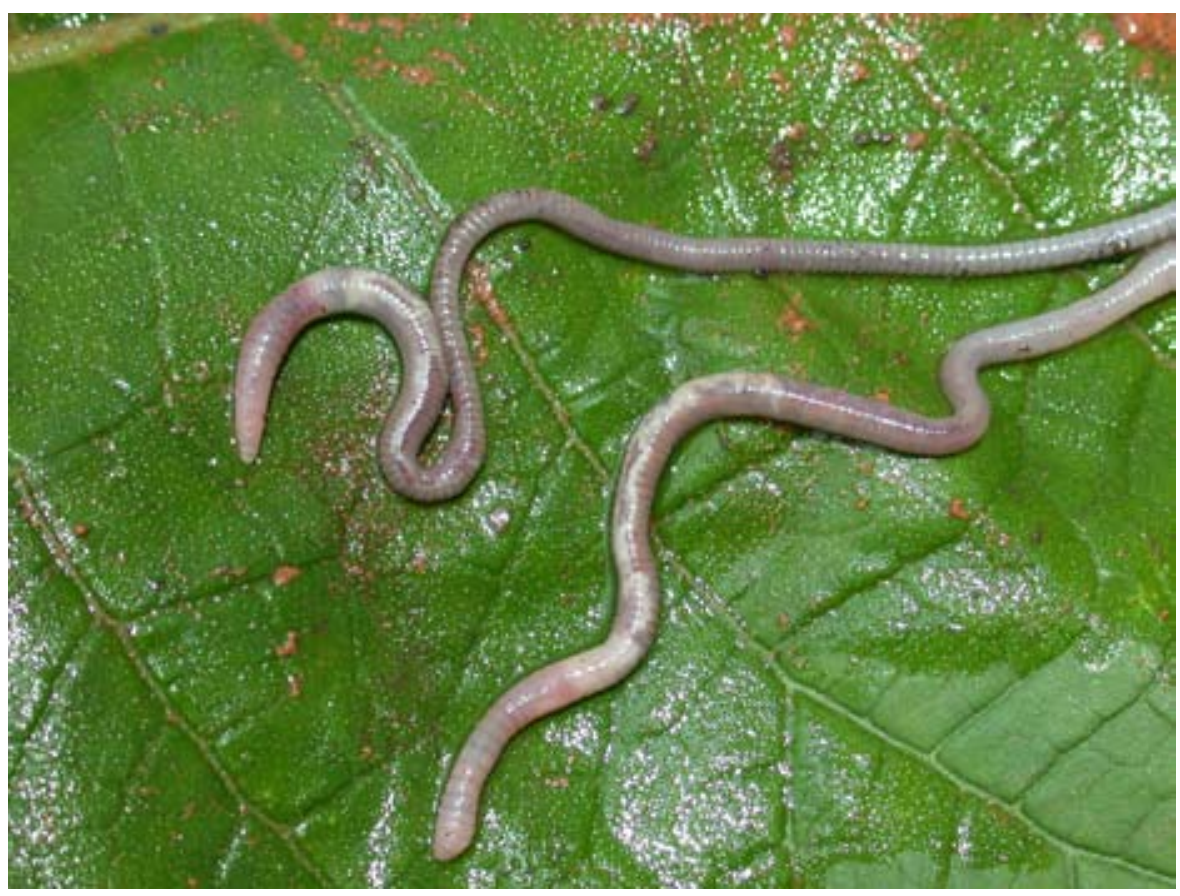

Figure 2. Two mature $F$. sporadochaetus. Note the long white seminal vesicles visible through the body wall. (Photo S. James)

tus is quite different from other Fimoscolex and the closely related Glossoscolex in having a copulatory chamber within the body wall rather than clearly distinct within the body cavity. From the location records now available for the species and genus (Table I), the potential range of the species may be much larger, considering the elevations and vegetation types from which it is known to occur. Clearly, the designation of extinct for $F$. sporadochaetus was premature, and did not include adequate fieldwork. The species is modestly sized with unremarkable features, and bears a superficial resemblance to the extremely common species, Pontoscolex corethrurus (Müller, 1857). Therefore it will not attract much attention, as would fall on the many giant earthworms known from southeastern Brazil, or those with bright coloration, or clearly different from worms commonly seen. Therefore, we expect that further exploration of the earthworm fauna of Minas Gerais, in the same general area, will yield more locations for $F$. sporadochaetus, as well as discovering many species previously unknown to science.

Fortunately, a chance meeting of the authors with the researchers responsible for establishing the Parque Estadual de Itacolomi's management plan at the Federal University of Minas Gerais in Belo Horizonte, aided in the establishment of high 


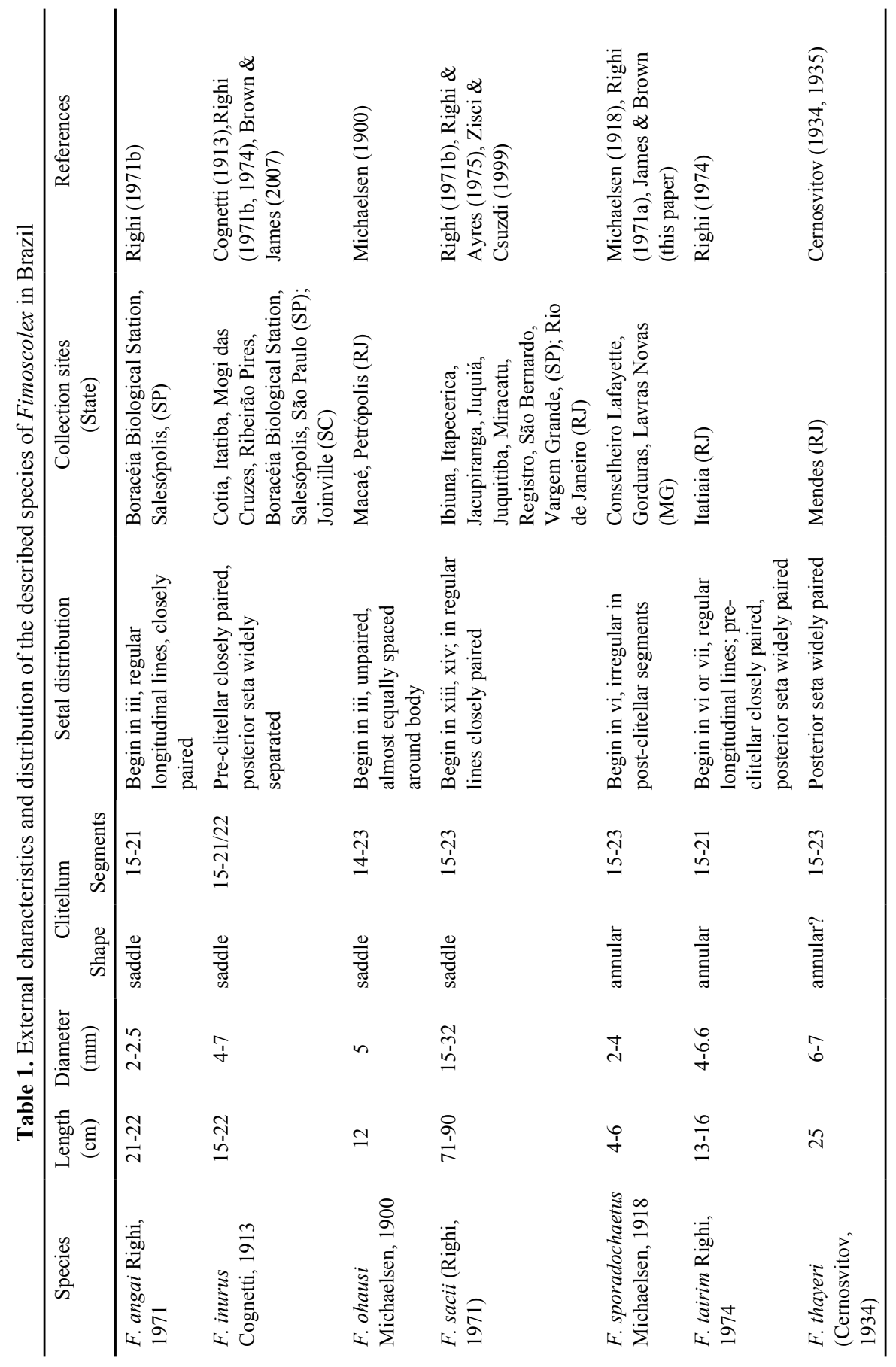


conservation priority status for the site where the earthworms were collected, thus guaranteeing their preservation.

\section{CONSIDERATIONS ON ENDANGERED EARTHWORM SPECIES AND THEIR DIVERSITY IN BRAZIL}

The present considerations are based on the author's collection records up to the present date and the known earthworm species diversity and distribution in Brazil (up until May 2006), synthesized in James \& Brown (2006) and Brown \& James (2007).

The vast majority $(>80 \%)$ of the more than 260 native earthworm species (including new, undescribed species) in Brazil have been collected in only one or two sites, generally the type locality and another location nearby (James \& Brown 2006). In some cases these records are recent, having been made during the 1966-1997 period in which the late Gilberto Righi was actively researching earthworms in South America, primarily Brazil. The remainder date as far back as 1835 (Leuckart 1835), with most occurring before 1937 (James \& Brown 2006). Thus a long time has elapsed between these records and the present, and in the interval few of the species have been collected. Close to 40 species have not been seen in more than 60 years (Brown \& James 2007). Formerly, IUCN (1994) considered that a species could be listed as endangered and even extinct under these circumstances, particularly when one considers the extensive habitat modification that has occurred throughout Brazil in the last 150 years. However, new IUCN criteria state that any species that has not been collected in a long time cannot be considered "endangered" until extensive collecting efforts have been made in its predicted home range (IUCN 2005).

But the sampling effort in the country is still grossly inadequate to properly consider the present status of possibly "endangered" species in Brazil. The mapping of all collection sites in the country up to December 2007 (Fig. 3) shows vast un-sampled regions (blank spaces on the map), containing large tracts of little-altered or slightly-altered habitat in the six major Brazilian biomes (Pampa, Pantanal, Atlantic Forest, Cerrado, Amazonia, Caatinga). On a closer geographic scale, say for instance, the state of São Paulo, with the greatest concentration of earthworm sample sites (120 of slightly over 700 points), the mapping of collection points (Fig. 3) still reveals an inadequate sampling effort, particularly in the Atlantic Forest and Cerrado biomes.

Several species of animals from the Atlantic Forest have been declared extinct and later been found, once collecting efforts increased to cover the full range of expected occurrence in the habitat (Brown \& Brown 1992). As seen for F. sporadochaetus, the designation of extinct was premature and not based on sufficient collection efforts. For $R$. alatus, the work of Drumond et al. (2008) vastly extended the range of occurrence, as the earthworms were collected more than $100 \mathrm{~km}$ from the original type collection site, and from where they are being sold (Paraopeba, MG). The species received a new conservation status and was considered near-threatened (NT), rather 


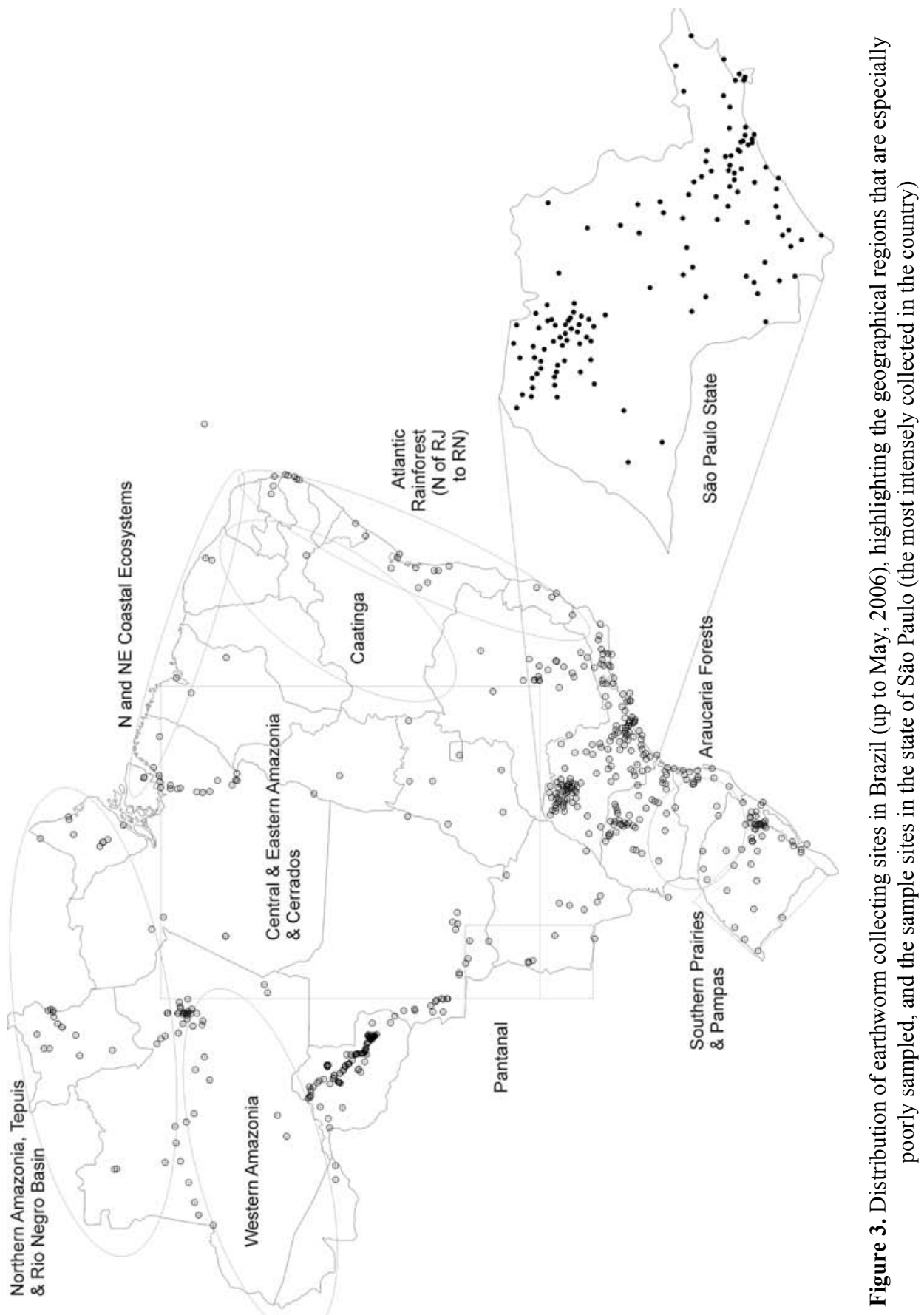


than endangered (Drumond et al. 2007). We believe that the other species also considered extinct ( $R$. fafner) may also still be living in some fragment(s) of the Atlantic Forest-Cerrado vegetation ecotone in the region surrounding Belo Horizonte. The finding of this species and the establishment of its conservation requirements are of utmost priority. The establishment of the actual range of $F$. sporadochaetus must also receive priority attention.

Considering the low dispersal abilities of earthworms and the "sensitivity" of some native species to disturbance, given their specificity for soil types, habitats, climatic conditions (Reynolds \& Jordan 1975), and the extensive alteration mainly in the Atlantic Forest biome (Brown \& Brown 1992), their habitats may require special protection. This is probably the case for some large minhocuçus in Brazil, as has also been observed for the giant Gippsland earthworm (Megascolides australis McCoy 1878) in Southern Australia. This "flagship" species has been used as a bargaining tool for the preservation of its specialized habitat in the region. For Brazilian earthworms, such an assessment is still a long ways off, given that much more data are still needed to properly assess distribution range, density in their habitat, and possibly specialized habitat preferences. Nonetheless, this should not prevent the competent authorities from setting aside special habitats or areas if particularly interesting earthworms are present, such as happened with $F$. sporadochaetus in the Parque Estadual do Itacolomi.

Conversely, considering the authors' collections up to date, mainly in Southeastern and Southern Brazil, it appears that for earthworms, despite extensive habitat alteration, especially in the Atlantic Forest biome (and its ecotone with the Cerrado), where only $7 \%$ of the original vegetation remains intact, even the highly fragmented nature of the preserved forest patches may be sufficient to sustain (at least until now) native species. Nevertheless, the individual and population-level home range size requirements of most earthworms species is still not known, and one can hypothesize that active surface-moving epigeics or large anecics (minhocuçus) may require larger areas of protected native habitat. Therefore, earthworm habitat conservation issues are likely to be more pressing for large worms (minhocuçus) and in the interior Atlantic Forest fragments (not along the coastal mountain range), especially in rare and highly fragmented ecosystems such as swampland forest, lowland plains forests, and other habitats that have been widely transformed by humans due to their more "usable" features (e.g., for agriculture).

Native earthworms appear to be fairly well preserved in the considerably large tracts of Atlantic Forest reserves along the Serra do Mar of the states of Paraná, Santa Catarina and São Paulo, although many of these sites have not yet been sampled. On the lower flanks of the Serra do Mar however, P. corethrurus appears to be abundant, and their omnipresence may be an indicator of the disappearance of native species or past disturbance (e.g., PE Carlos Botelho-SP and PE da Graciosa-PR). Some of the 
species native to this habitat have not been seen in a long time, although they may still be present in other patches of forest, outside their presently known collection sites. Examples of these are several species of Glossoscolex (G. catharinensis, G. colonorum, $G$. wiengreeni) that have been collected in selected sites of the Serra do Mar Atlantic Forest from Rio de Janeiro to Rio Grande do Sul.

Unfortunately, not enough is yet known of the ability of native earthworm species to survive over the long-term in slightly altered habitats, typical of the Atlantic Forest biome. This appears to be an important issue, considering the presence of many invading species, in particular Amynthas spp. (and other Megascolecids) and Pontoscolex corethrurus in these forest fragments (Fernandes et al., this issue). These species have spread extensively throughout Brazil, mainly due to human-facilitated dispersal (Brown et al. 2006), and may have negative interactions (still not studied) with the native earthworm species. For instance, when analyzing all the sites where quantitative sampling has been performed in Brazil, Brown \& James (2007) found that native species tended to dominate in little-disturbed forests, while exotics tended to be equally important as natives in secondary forests and generally predominated in agroecosystems (Fig. 4).

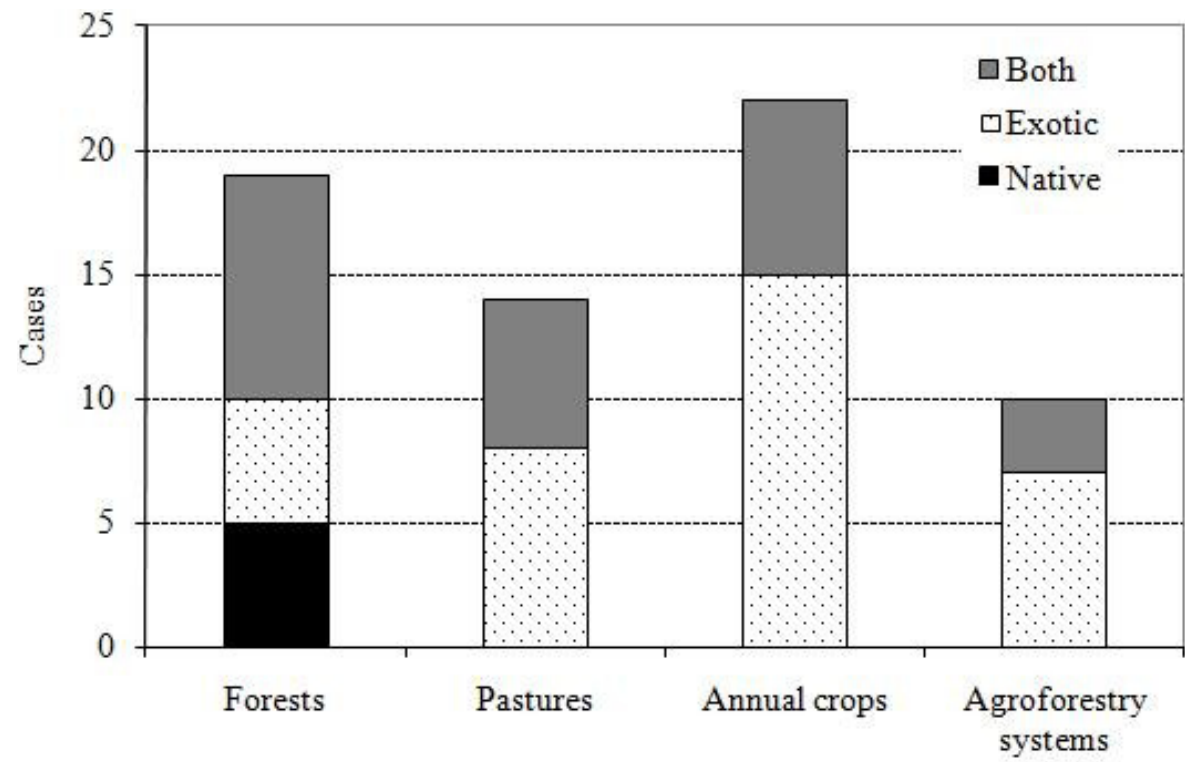

Figure 4. Number of cases in which native and/or exotic earthworms were found in various Brazilian ecosystems. Data from a total of 65 sites where quantitative earthworm sampling (biomass and/or density measurements) were performed (modified from Brown \& James 2007). Native forests with only exotic species were in secondary vegetation 
Studies on the basic biology of most Brazilian species are also still lacking. Hence, some species could be targeted for more research and a special designation of "data deficient" (DD; IUCN 2005, Machado et al. 2005) could be granted, so that they may be subjected to further investigation. At present 29 species, 19 of them from the Atlantic Forest biome have been suggested for this status (Brown \& James 2007). Nevertheless, we believe that many other species probably deserve the same status.

\section{CONCLUDING REMARKS}

Conservation issues concerning native earthworms in Brazil are likely to be related to both size of the earthworm and size and fragmentation of the original habitat. Not enough is known of the biology or habitat requirements of most species and much more work, both on basic biology and intensified sampling efforts are necessary to properly ascertain the true status of "danger" that some species may be facing. We are still in the earthworm description phase, and the discovery of many new species, has highlighted the immense diversity of earthworms that likely live in Brazil. Effective earthworm conservation depends first on adequate characterization of the sensitivity of particular earthworm species to habitat disturbance and the present status and current trends in the preservation of the integrity of these habitats. Ideally, the description and inventory data should feed into the ecological decisions on the management and conservation of particular habitats, as occurred with $F$. sporadochaetus in the PE do Itacolomi. Some earthworms may be sensitive indicators of disturbance, and these potentials must be further explored with field research, and developed in partnership and cooperation with conservation agencies.

\section{ACKNOWLEDGEMENTS}

The authors thank IBAMA and the Instituto Florestal (IF) of Minas Gerais for the sampling and research permits, the USA National Science Foundation award DEB0516439 to the first author, and Prodetab, CNPq and Fulbright for scholarships and financial support.

\section{LITERATURE CITED}

Bouché, M. B. 1983. The establishment of earthworm communities. Pp. 431-448. In: J. E. Satchell (Ed.). Earthworm ecology: From Darwin to vermiculture. Chapman \& Hall, London

Brown Jr., K. S. \& G. G. Brown. 1992. Habitat alteration and species loss in Brazilian forests. Pp. 119-142. In: T. C. Whitmore and J. A. Sayer (Eds.). Tropical deforestation and species extinction. Chapman \& Hall, London.

Brown, G. G. \& S. W. James. 2007. Ecologia, biodiversidade e biogeografia das minhocas no Brasil. Pp. 297-381. In: G. G. Brown and C. Fragoso (Eds.). Minhocas na América Latina: Biodiversidade e ecologia. Embrapa Soja, Londrina. 
James \& Brown: Rediscovery of F. sporadochaetus

Brown, G. G., S. W. James, A. Pasini, D. H. Nunes, N. P. Benito, P. T. Martins \& K. D. Sautter. 2006. Exotic, peregrine and invasive earthworms in Brazil: diversity, distribution and effects on soils and plants. Caribbean Journal of Science. 42: 339-358.

Cernosvitov, L. 1934. Les Oligochètes de la Guyane Française et d'autres pays de l'Amérique du Sud. Bulletin du Museum Nationale d'Histoire Naturelle de Paris. 2 (6): 47-59.

Cernosvitov, L. 1935. Oligochaeten aus dem tropischen Sud Amerika. Capita Zoologica. 6: 1-36.

Cognetti de Martiis, L. 1913. Contributo alla conoscenza del genero Fimoscolex. Zoologische Jahrbucher Abteilung für Systematik. 34: 615-632.

Drumond, M. A., S. H. C. Campos, A. Q. Guimarães, R. P. Martins, L. C. Giovanetti \& M. Matteuzo. 2007. Distribuição geográfica do minhocuçu Rhinodrilus alatus, Righi, 1971, e sua contribuição para a revisão do status de conservação da espécie. Pp. 1-2. In: Anais do VIII Congresso de Ecologia do Brasil, 23-28 September 2007, Caxambu, Brazil. CD-ROM.

Drumond, M. A., S. H. C. Campos, A. Q. Guimarães \& J. T. Nunes. 2008. Uso e conservação do minhocuçu Rhinodrilus alatus. MG Biota. 1: 5-23.

IUCN. 1994. IUCN Red list categories. IUCN Species Survival Commission, IUCN, Gland.

IUCN. 2005. Guidelines for using the IUCN red list categories and criteria. IUCN, Gland.

James S. W. \& G. G. Brown. 2006. Earthworm ecology and diversity in Brazil. Pp. 56-116. In: F. M. S. Moreira, J.O. Siqueira and L. Brussaard (Eds.). Soil biodiversity in Amazonian and other Brazilian ecosystems. CABI, Wallingford.

Leuckart, F. 1835. Abbildung einer neuer Genus Ringelwurm. Notizen Froriep. 46: 88.

Machado, A. B. M., C. S. Martins \& G. M. Drummond. 2005. Lista da fauna brasileira ameaçada de extinção, incluindo as listas das espécies quase ameaçadas e deficientes em dados. Fundação Biodiversitas, Belo Horizonte.

Michaelsen, W. 1900. Zur Kenntnis der Geoscoleciden Sudamerikas. Zoologischer Anzeiger. 23(606): 53-56.

Michaelsen, W. 1918. Die Lumbriciden. Zoologische Jahrbucher Abteilung für Systematik. 41: 1-398.

MMA. 2003. Lista de espécies da fauna brasileira ameaçada de extinção. Anexo à instrução normativa $N^{o} 3$ de 27 de maio de 2003, do Ministério do Meio Ambiente. MMA, Brasília. (see www.biodiversitas.org.br).

Reynolds, J. W. 1994. Earthworms of the world. Global Biodiversity. 4: 11-16.

Reynolds, J. W. \& G. A. Jordan. 1975. A preliminary conceptual model of megadrile activity and abundance in the Haliburton Highlands. Megadrilogica. 2(2): 1-9.

Reynolds, J. W. \& M. J. Wetzel. 2010. Nomenclatura Oligochaetologica, suplementum quartum. Illinois Natural History Survey Special Publication, Champaign, USA. In press. (see http://www.inhs. uiuc.edu/ mjwetzel/Nomen.Oligo.html).

Righi, G. 1971a. Sobre alguns Oligochaeta Brasileiros. Papéis Avulsos de Zoologia. 25(1): 1-14.

Righi, G. 1971b. Sobre a família Glossoscolecidae (Oligochaeta) no Brasil. Arquivos de Zoologia. 20(1): 1-95.

Righi, G. 1974. Notas sobre as Oligochaeta Glossoscolecidae do Brasil. Revista Brasileira de Biologia. 34: 551-564.

Righi, G. 1998. Oligoquetas. Pp. 571-583. In: A. B. M. Machado, G. A. B. da Fonseca, R. B. Machado, L. M. de S. Aguiar and L.V. Lins (Eds.). Livro vermelho das espécies ameaçadas de extinção da fauna de Minas Gerais. Fundação Biodiversitas. Belo Horizonte.

Righi, G. \& I. Ayres. 1975. Alguns Oligochaeta sul brasileiros. Revista Brasileira de Biologia. 35:309316.

Zicsi, A. \& C. Csuzdi. 1999. Neue und bekannte regenwürmer aus verschiedenen Teilen Südamerikas. Regenwürmer aus Südamerika 26. Senckenbergiana Biologica. 78:123-134. 